\title{
ARTÍCULOS
}

\section{PRODUCING POLITICAL CONTENT FOR WEB 2.0: EMPOWERING CITIZENS AND VULNERABLE POPULATIONS}

\section{Producción de contenidos políticos, empoderamiento ciudadano y públicos vulnerables en la web 2.0}

\section{Andreu Casero-Ripollés}

Nota: Este artículo se puede leer en español en:

http://www.elprofesionaldelainformacion.com/contenidos/2017/ene/02_esp.pdf

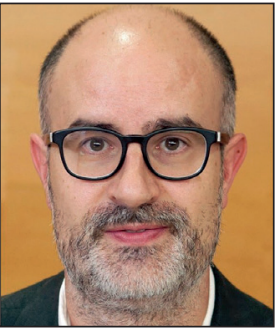

Andreu Casero-Ripollés is an associate professor and head of Department of Communication Sciences at the Universitat Jaume I de Castelló (Spain). He holds a degree from the Universitat Autònoma de Barcelona and a PhD from the Universitat Pompeu Fabra. He is a member of the Institut $d^{\prime}$ Estudis Catalans. He has been a visiting researcher at the universities of Columbia (United States) and Westminster (UK), among others. He studies political communication and the transformation of journalism in the digital environment. He has published articles in journals such as Information, Communication \& society, International journal of press/politics, American behavioral scientist and International journal of communication.

http://orcid.org/0000-0001-6986-4163

Universitat Jaume I de Castelló, Facultat de Ciències Humanes i Socials, Departament de Ciències de la Comunicació Avda. Vicent Sos Baynat, s/n. 12071 Castelló de la Plana, España casero@uji.es

\begin{abstract}
Social media, or web 2.0, allows citizens to produce content and information. However, not everybody has the same access to these benefits. This causes the emergence of a digital divide and the appearance of vulnerable sectors. We study the effect of education, financial income, and the frequency of technology use on the capacity of citizens to produce political content on social media in Spain. The methodology is based on a secondary analysis of data, whereby a statistical method was applied to a quantitative questionnaire $(n=2,444)$. The results reveal that citizens' creation of political content depends more on education level and frequency of digital network use, rather than on income levels. This data provides a significant and novel contribution to the awareness of factors that determine digital inequality.
\end{abstract}

\section{Keywords}

Social media; Web 2.0; Citizen empowerment; Digital democracy; Political communication; Digital inequalities.

\section{Resumen}

Los medios sociales, o web 2.0, permiten a los ciudadanos producir contenidos e informaciones. Sin embargo, no todos acceden por igual a estos beneficios. Esto genera la emergencia de desigualdades digitales y la aparición públicos vulnerables. Nuestro objetivo es estudiar la incidencia de la educación, los ingresos económicos y la frecuencia de utilización de las tecnologías en la capacidad de los ciudadanos de producir contenidos políticos en los medios sociales en España. La metodología se basa en el análisis secundario de datos a partir de la aplicación del método estadístico a una encuesta cuantitativa $(n=2.444)$. Los resultados revelan que la creación de contenidos políticos por parte de los ciudadanos depende de la educación y la intensidad de uso de las redes digitales, aunque no tanto del nivel de ingresos. Estos datos realizan una aportación significativa y novedosa al conocimiento de los factores que determinan la desigualdad digital.

\section{Palabras clave}

Medios sociales; Web 2.0; Empoderamiento ciudadano; Democracia digital; Comunicación política; Desigualdades digitales.

Casero-Ripollés, Andreu (2017). "Producing political content for web 2.0: Empowering citizens and vulnerable populations". El profesional de la información, v. 26, n. 1, pp. 13-19. 


\section{Introduction}

Social media (also known as web 2.0) is a concept that encompasses technologies including social networks, microblogs, blogs, or social video portals, and promotes new communication options for citizens. By means of social media citizens can communicate and interact with others by producing their own content and presenting it to a potentially broad audience (Jenkins, 2006). This possibility has diverse democratic implications as it can encourage citizen participation in public debates, promote pluralism, and reconfigure valid power relations (Castells, 2009). This opens up the prospect of reformulating citizens' roles in the articulation of public opinion and political communication.

However, the bibliography has proven that not all citizens have equal access to social media's benefits, in terms of content production (Hargittai; Hsieh, 2013). Digital inequalities consequently appear and turn specific social groups vulnerable, as they are excluded from the advantages generated by 2.0 platforms. This produces democratic costs. Thus, it is essential to analyze the social factors that create vulnerable sectors, as well as the factors that condition and limit the use of digital technologies. Our objective is to study the effect of education, financial income, and the frequency of technology use on citizens' capacity to produce political content and information for web 2.0 in Spain.

\section{Bibliographic revision: Citizen empowerment and production of political content on the web $\mathbf{2 . 0}$}

Social media has inspired theories about public empowerment:

- on the one hand, thanks to its potential, citizens can produce and spread communicative content (instead of simply consuming) (Jenkins, 2006; Castells, 2009);

- and on the other hand, social media platforms facilitate communal activities and promote connectedness as a social value (Van-Dijck, 2013).

These conditions enable citizens to act as a counterbalance and compensate for the influence of political, financial, and media elites in the configuration of the public debate (Castells, 2009). In this regard, web 2.0 gives:

- users a chance to participate in public discussions by freely expressing their opinions (Shirky, 2011);

- users can also inversely implement public agenda building dynamics (Sung-Tae; Young-hwan, 2007);

- even begin political monitoring processes to supervise political, financial, and media powers (Keane, 2009; Feenstra; Casero-Ripollés, 2014).

Cáceres-Zapatero; Brändle; Ruiz-San-Román (2015) showed that the Internet generates the feeling of empowerment for approximately half of the population in Spain.

These new possibilities of social media pave the way for a redefinition of citizens' roles in the classic triangle of political communication. In the past, citizens fulfilled a passive role, merely viewing the interactions between journalists and political actors who controlled and defined the field (Wolton, 1989). According to this theoretical perspective, web 2.0 is equipped with two democratic potentials:
- first of all, it entitles citizens to participate in politics as it enhances their influence;

- secondly, it provides an opportunity to increase the public's civil obligations, strengthen democracy, and reduce disaffection.

A crucial dimension for these potentials is the reduction of costs for users to create content in a digital environment. As such, the production of political information becomes easy, fast, and cheap. Through social media platforms, users can prepare and spread messages easily and autonomously. Some argue that this will place creation out of the hands of the elites, introducing it to more citizens, thus reinforcing democracy and facilitating greater participation in the public sphere (Jenkins, 2006; Castells, 2009; Benkler, 2015). Expressing and sharing thoughts or comments, which constitutes one form of political content created through web 2.0, is an action that leads to citizen empowerment, along with a wide range of practices (Cáceres-Zapatero; Brändle; Ruiz-San-Román, 2015).

\section{The production of political information becomes easy, fast, and cheap in the di- gital environment}

Producing political content is a highly valuable resource for social movements, activists, and the general public when activating, articulating, advertising, and expanding protests. In some cases, such as the $15-M$ movement in Spain or the Occupy movement in the United States and Great Britain, anonymous individuals made and publicized content (MicóSanz; Casero-Ripollés, 2014). Additionally, activists even implemented resources of an alternative nature as an instrument of protest. In this regard, the digital environment could contribute to the emergence of new informative actors (Tewksbury; Rittenberg, 2012). Thus, the creation of content by the public through web 2.0 turns into a defining and central element of a new kind of political activism (Lievrouw, 2011). Producing this type of content is a key aspect of citizens' political participation (Blank, 2013), although it is not the only defining factor of this participation (Zallo, 2013).

With respect to these approaches, other authors uphold that, despite its possibilities, social media has limits in terms of its capacity for citizen empowerment and for the transformation of democracy. The first criticism concerns the fact that for most citizens, political participation through web 2.0 involves minimum civil obligation. Users simply need to interact with a technological device, such as a computer or digital tablet, and conveniently click from home; as such, these citizens favor a comfortable or low-risk form of activism, also known as slacktivism or clicktivism (Gladwell, 2010; Morozov, 2013). Their involvement is sporadic and discontinuous with little capacity to mobilize, as these individuals are not willing to protest in public or in the streets to defend their beliefs. Thus, in these cases, the support for a cause or protest through social media has minimal political impact and low-to-null practical effects on the democratic 
dynamic, as this form of activism only serves to increase participants' feeling of well-being (Morozov, 2011).

Secondly, several authors indicate that digital networks are less popularly used for political purposes, as opposed to entertainment and social interaction uses (Van-Dijck, 2013). Politics is still a minority issue on social media, despite its increasing usage in recent years (Dahlgren, 2013), something that has been evidenced empirically in the Spanish case (Fundación Telefónica, 2016). Furthermore, the digital environment imposes an economy of attention that generates disparities (Fuchs, 2014). Any citizen may produce and disseminate information, but not all content has the same visibility at all levels of society. Despite the fact that anyone can use digital networks, not all users are equal. Some users possess more advantages on social media due to their fame or power. They thus create strong doses of attention and they amass large followings, which amplifies their reach and visibility. This establishes limits, in terms of counterbalancing the citizen and web 2.0's capacity, for social influence.

Lastly, another essential issue concerning citizen empowerment on web 2.0 is related to the requirement of certain technical and cognitive digital abilities (DiMaggio; Hargittai, 2001; Van-Deursen; Van-Dijk, 2011). Above all, communicative cognitive competencies are required; this includes refined search strategies, a critical capacity to assess content credibility, and the ability to prepare content efficiently (Hoffmann; Lutz; Meckel, 2015; Hargittai; Hsieh, 2013). However, not all individuals possess these abilities to the same extent, and as a consequence there are differences on their capacity to exploit social media in terms of power generation; this therefore becomes a source of the digital divide. The big question is: what factors affect individuals' digital communication competencies?

When answering this question, the scientific bibliography has focused more on the acquisition of information than on the production of content. Many researchers have demonstrated that information acquisition is not equal across digital networks; instead, it continues to be based on stratification, thus promoting exclusions and the digital divide (Hargittai; Hsieh, 2013). Age, gender, race, and (predominantly) socioeconomic factors lead to differences between users' abilities to access political information (Norris, 2015). This shows that not all citizens have the same opportunities and that the digital environment establishes cognitive differences, which creates vulnerable sectors and a gap between the information-rich and the information-poor (Bonfadelli, 2002; Haywood, 1995).

However, an analysis of the factors that affect citizens' content production capacity on social media has received limited attention (Hargittai; Walejko, 2008; Blank, 2013; Hoffmann; Lutz; Meck, 2015). In general, previous research reveals the persistence of social inequality in digital content creation (Schradie, 2013). However, the results were ambiguous and inconclusive. In university-centred studies, Hargittai and Walekjo (2008) and Correa (2010) confirm that education is not a determining factor in the production of digital content. On the other hand, Schradie (2011) and Blank (2013) show that education does have a significant effect.
With regards to income, both Hargittai and Walejko (2008) and Van-Deursen and Van-Dijk (2011) link individuals' economic level to a greater capacity for creating digital content. On the other hand, past experience with content creation and Internet-management tasks are both positively associated with content production (Hargittai; Walekjo, 2008; Cáceres-Zapatero; Brändle; Ruiz-San-Román, 2015).

Nevertheless, these limited results are not conclusive. Consequently, there are numerous aspects that require further clarification. This research intends to fill this gap. For this purpose, the Spanish case is studied, as the $15-\mathrm{M}$ movement of 2011 was significant internationally because of the digital mobility and activism it initiated, which was subsequently continued by diverse social segments (Casero-Ripollés, 2015). The objective is to study the effect of education, financial income, and the frequency of digital technology use on citizens' capacity to produce political content for web 2.0 in Spain. The initial hypothesis upholds that these three factors directly and positively affect citizens' production of political information. In this regard, people who perform poorly on these three variables are considered to be part of the vulnerable sectors.

Not all citizens have equal access to social media's benefits in terms of content production

\section{Methodology}

The methodology is based on secondary analysis of data, whereby a statistical method is applied to the results obtained from a quantitative questionnaire. Thus, the barometer n. 3,038 (published in September 2014 in Spain) from the Centre for Sociological Research (CIS) was used.

http://www.cis.es/cis/opencms/ES/NoticiasNovedades/ InfoCIS/2014/Documentacion_3038.html

In this survey, 2,444 Spanish residents between the ages of 18 and 95 years were interviewed. At the $95.5 \%$ confidence level, the actual error of the entire sample is $\pm 2.0 \%$.

Out of the three types of digital content produced by citizens: expert, entertainment, and politics, the last ones are analyzed. This is why the action of writing comments about current political and social events on digital networks is implemented, in line with earlier bibliography (Blank, 2013). It was determined that the dependent variable would be "Writing comments about current, social or political topics on a forum, blog, social network, etc.").

As such, the independent variables were:

- education level;

- the level of personal financial income; and

- the frequency of social network use.

The choice of education and income is based on the fact that it deals with factors traditionally used within the bibliography (Hargittai; Hsieh, 2013). On the other hand, exploiting the frequency of use is justified by its connection with users' specific digital competency requirements, an aspect that may limit citizen empowerment on the Internet (DiMaggio; Hargittai, 2001). 
The statistical crossing of dependent variables $(\mathrm{Y})$ and independent variables $(X)$ has been carried out by means of the SPSS program. Calculating the Pearson correlation coefficient $(r)$ and the dependency coefficient $\left(R^{2}\right)$ has been done by means of established mathematical formulas; it will determine the degree of dependency between both variables, as well as the relationship (whether positive or negative) among them.

Some variables were recoded as certain values included a very low number of subjects. In these cases, the reduced character of the sample determined its restricted representativeness that skewed the results. Thus, the highest income levels (i.e. "between 2,401 and 3,000"; "between 3,001 and 4,500"; "between 4,501 and 6,000" and "over 6,000 Euros") were consolidated into a single category called "over 2,401 Euros" that, after this operation, does in fact include an representative number of individuals. Similar groupings have been made with certain values relative to the level of education.

People who are less educated are configured as vulnerable sectors in terms of creation of political content on social media

\section{Results}

Statistical analysis results relative to the level of education reveal the existence of a relationship between the degree of academic training and the use of social media to create and disseminate political content $\left(X^{2}=131.899, g l=7, p=0.000\right)$ (table 1). The percentages of people who write messages with lower education levels (linked to categories such as "less than 5 years of education" and "elementary school") are $0 \%$ and $4.5 \%$ respectively (Table 1 ). Similarly, these fi- gures increase as the level of education ascends to $42.9 \%$ in postgraduate studies, corresponding to a master's degree, and $35.5 \%$ for individuals who have obtained a PhD. The Pearson correlation coefficient is set on one of the highest values $(r=0.957)$, revealing that the relationship between these variables is positive and strong. Similarly, the coefficient of determination $\left(R^{2}=0.915\right)$ is high, further supporting this finding. With these results, we can decisively conclude that education greatly impacts the creation of political content on digital networks, conditioning it decisively.

\section{Social media has inspired theories about public empowerment}

On the other hand, statistical analysis reveals that an individual's level of financial income is poorly related to a citizen's use of social media to produce political information $\left(X^{2}=30.576, g l=7, p=0.000\right.$ ) (Table 2). The analysis of correlation between variables shows that this relationship, albeit positive, is very weak as the Pearson coefficient is $r=0.072$ and the coefficient of determination is $R^{2}=0.005$. These values explain that opposite ends are modified in the results. Consequently, the categories corresponding to a greater financial vulnerability (no income and less than 300 Euros monthly) record percentages similar to those obtained by categories linked to a more favorable financial status (income between 1,801 and 2,400 Euros and greater than 2,401 Euros monthly) (Table 2). The practical equivalence of these figures together with the values of the correlation between variables shows that the level of income does not have a direct and conditioning effect on a citizen's use of web 2.0 to create political content. In other words, greater income does not result in a greater percentage of content creators.

Table 1. Influence of the level of education in the production of political content for web 2.0

\begin{tabular}{|c|c|c|c|c|c|c|c|c|c|c|c|}
\hline & & & \multicolumn{8}{|c|}{ Interviewee's level of education } & \multirow[b]{2}{*}{ Total } \\
\hline & & & $\begin{array}{l}\text { Less than } \\
5 \text { years of } \\
\text { educa } \\
\text { tion }\end{array}$ & $\begin{array}{l}\text { Primary } \\
\text { educa- } \\
\text { tion }\end{array}$ & $\begin{array}{l}\text { Secondary } \\
\text { education }\end{array}$ & $\begin{array}{l}\text { Voca- } \\
\text { tional } \\
\text { training }\end{array}$ & A levels & $\begin{array}{c}\text { Uni- } \\
\text { versity } \\
\text { studies }\end{array}$ & $\begin{array}{c}\text { Postgra- } \\
\text { duate } \\
\text { studies }\end{array}$ & PhD & \\
\hline \multirow{4}{*}{$\begin{array}{l}\text { Write comments } \\
\text { about current, } \\
\text { social, or political } \\
\text { topics on a fo- } \\
\text { rum, blog, social } \\
\text { network, etc. }\end{array}$} & \multirow[b]{2}{*}{ Yes } & Count & 0 & 14 & 71 & 96 & 90 & 135 & 12 & 6 & 424 \\
\hline & & $\begin{array}{l}\text { \% within the } \\
\text { interviewee's } \\
\text { level of } \\
\text { education }\end{array}$ & 0.0 & 4.5 & 12.1 & 22.5 & 29.4 & 29.5 & 42.9 & 35.3 & 19.7 \\
\hline & \multirow[b]{2}{*}{ No } & Count & 24 & 294 & 514 & 331 & 216 & 323 & 16 & 11 & 1,729 \\
\hline & & $\begin{array}{l}\% \text { within the } \\
\text { interviewee's } \\
\text { level of } \\
\text { education }\end{array}$ & 100.0 & 95.5 & 87.9 & 77.5 & 70.6 & 70.5 & 57.1 & 64.7 & 80.3 \\
\hline \multirow[b]{2}{*}{ Total } & & Count & 24 & 308 & 585 & 427 & 306 & 458 & 28 & 17 & 2,153 \\
\hline & & $\begin{array}{l}\text { \% within the } \\
\text { interviewee's } \\
\text { level of } \\
\text { education }\end{array}$ & 100.0 & 100.0 & 100.0 & 100.0 & 100.0 & 100.0 & 100.0 & 100.0 & 100.0 \\
\hline
\end{tabular}

$\left(X^{2}=131.899, g \mid=7, p=0.000\right)$ 
Table 2. Influence of financial income in the production of political content for web 2.0

\begin{tabular}{|c|c|c|c|c|c|c|c|c|c|c|c|}
\hline & & & \multicolumn{8}{|c|}{ Income of interviewee $(€)$} & \multirow[b]{2}{*}{ Total } \\
\hline & & & $\begin{array}{c}\text { No } \\
\text { income }\end{array}$ & $\begin{array}{c}\text { Less than } \\
\text { or equal } \\
\text { to } 300\end{array}$ & $\begin{array}{c}\text { From } \\
301 \text { to } \\
600\end{array}$ & $\begin{array}{c}\text { From } 601 \\
\text { to } 900\end{array}$ & $\begin{array}{c}\text { From } 901 \\
\text { to } 1,200\end{array}$ & $\begin{array}{l}\text { From } \\
1,201 \text { to } \\
1,800\end{array}$ & $\begin{array}{l}\text { From } \\
1,801 \text { to } \\
2,400\end{array}$ & $\begin{array}{l}\text { More } \\
\text { than } \\
2,401\end{array}$ & \\
\hline \multirow{4}{*}{$\begin{array}{l}\text { Write comments } \\
\text { about current, } \\
\text { social, or poli- } \\
\text { tical topics on } \\
\text { a forum, blog, } \\
\text { social network, } \\
\text { etc. }\end{array}$} & \multirow[b]{2}{*}{ Yes } & Count & 80 & 20 & 38 & 39 & 60 & 45 & 36 & 9 & 327 \\
\hline & & $\begin{array}{l}\% \text { within } \\
\text { Income of } \\
\text { interviewee }\end{array}$ & 19.1 & 34.5 & 14.9 & 15.0 & 20.6 & 17.8 & 34.3 & 20.0 & 19.4 \\
\hline & \multirow[b]{2}{*}{ No } & Count & 339 & 38 & 217 & 221 & 231 & 208 & 69 & 36 & 1359 \\
\hline & & $\begin{array}{l}\text { \% within } \\
\text { Income of } \\
\text { interviewee }\end{array}$ & 80.9 & 65.5 & 85.1 & 85.0 & 79.4 & 82.2 & 65.7 & 80.0 & 80.6 \\
\hline \multirow{2}{*}{\multicolumn{2}{|c|}{ Total }} & Count & 419 & 58 & 255 & 260 & 291 & 253 & 105 & 45 & 1,686 \\
\hline & & $\begin{array}{l}\% \text { within } \\
\text { Income of } \\
\text { interviewee }\end{array}$ & 100.0 & 100.0 & 100.0 & 100.0 & 100.0 & 100.0 & 100.0 & 100.0 & 100.0 \\
\hline
\end{tabular}

$\left(X^{2}=30.576, g \mid=7, p=0.000\right)$

Lastly, the statistical analysis shows that the frequency of social network use is established as a factor that conditions citizens' creation of political content on social media $\left(X^{2}=40.895, g l=6, p=0.000\right)$. Thus, variables displaying a more intense use of digital networks have higher values, while those that induce lower usage frequencies, in turn, have lower percentages. In this sense, $47 \%$ of individuals who continuously use web 2.0 produce political information in this environment (Table 3 ). However, just $13.3 \%$ of individuals who almost never use these platforms are content creators. The value of the Pearson correlation coefficient $(r=0.927)$ reaffirms the positive and strong relationship between these variables. On the other hand, the coefficient of determination $\left(R^{2}=0.861\right)$ indicates that there is a relatively linear relationship but one with some fluctuation, which is related to the "every several weeks" category. This category reduces the adjustment of data on the line and the goodness of the model. Even so, a more regular and intense use of web 2.0 requires greater content creation by citizens through these platforms. As a result, the use is configured as a conditioning factor that is able to create inequalities, based on its intensity, among citizens.

The creation of political content on social media depends on the users' level of education and their frequency of use

\section{Conclusions}

The results of the Spanish case study partially prove our initial hypothesis: the creation of political content on social media depends on the user's level of education and their frequency of digital network use; however, it disregards the level of financial income. Academic training and use intensity are capable of generating social and political capital among citizens on social networks. Thus, people who are more educated and use social media are at a greater ad-

Table 3. Influence of the frequency of social networks use in the production of political content for web 2.0

\begin{tabular}{|c|c|c|c|c|c|c|c|c|c|c|}
\hline & & & \multicolumn{7}{|c|}{ Frequency of social networks use } & \multirow[b]{2}{*}{ Total } \\
\hline & & & $\begin{array}{c}\text { Continu- } \\
\text { ously }\end{array}$ & $\begin{array}{c}\text { Several } \\
\text { times a } \\
\text { day }\end{array}$ & $\begin{array}{c}\text { Once per } \\
\text { day }\end{array}$ & $\begin{array}{c}\text { From three } \\
\text { to five times } \\
\text { per week }\end{array}$ & $\begin{array}{c}\text { From one to } \\
\text { two times } \\
\text { per week }\end{array}$ & $\begin{array}{l}\text { Every } \\
\text { couple of } \\
\text { weeks }\end{array}$ & $\begin{array}{c}\text { Almost } \\
\text { never }\end{array}$ & \\
\hline \multirow{4}{*}{$\begin{array}{l}\text { Write comments } \\
\text { about current, } \\
\text { social or political } \\
\text { topics on a fo- } \\
\text { rum, blog, social } \\
\text { network, etc. }\end{array}$} & \multirow[b]{2}{*}{ Yes } & Count & 95 & 129 & 99 & 23 & 20 & 9 & 6 & 381 \\
\hline & & $\begin{array}{l}\% \text { within Fre- } \\
\text { quency of social } \\
\text { networks use }\end{array}$ & 47.0 & 36.5 & 33.4 & 24.0 & 19.0 & 25.7 & 13.3 & 33.7 \\
\hline & \multirow[b]{2}{*}{ No } & Count & 107 & 224 & 197 & 73 & 85 & 26 & 39 & 751 \\
\hline & & $\begin{array}{l}\% \text { within Fre- } \\
\text { quency of social } \\
\text { networks use }\end{array}$ & 53.0 & 63.5 & 66.6 & 76.0 & 81.0 & 74.3 & 86.7 & 66.3 \\
\hline \multirow{2}{*}{\multicolumn{2}{|c|}{ Total }} & Count & 202 & 353 & 296 & 96 & 105 & 35 & 45 & 1,132 \\
\hline & & $\begin{array}{l}\% \text { within Fre- } \\
\text { quency of social } \\
\text { networks use }\end{array}$ & 100.0 & 100.0 & 100.0 & 100.0 & 100.0 & 100.0 & 100.0 & 100.0 \\
\hline
\end{tabular}

$\left(X^{2}=40.895, g l=6, p=0.000\right)$ 
vantage than those who do not. The latter are configured as vulnerable sectors. This results in the emergence of a digital divide that affects the democratic potential of social media platforms, as they reach some citizens more than others.

Despite being a powerful equalizer, web 2.0 can strengthen existing inequalities and expand them. While it is true that social media can enable citizen empowerment, it does not automatically occur. Not everyone has equal access or potential to use these platforms. The acknowledgement of the vulnerable sectors' existence demonstrates that social stratification is generated on social media and that there is an asymmetrical distribution of civic power. Those who hold privileged social positions due to their educational level and frequent Internet use have an advantage with respect to those who do not and, thus, their superiority is strengthened. The distance between both types of citizens can be seen in the digital environment with regard to the production of political content.

The level of income does not have a direct and conditioning effect on citizens' use of web 2.0 to create political content

The statistical data analysis of the Spanish case reinforces the bibliography's findings regarding the impact of education on citizens' production of content and political information (Schradie, 2011; Blank, 2013). Academic training is expressed as a conditioning factor that can exclude and limit the democratic potential of social media. Similarly, this study reaffirms previous research's findings (Hargittai; Walekjo, 2008; Cáceres-Zapatero; Brändle; Ruiz-San-Román, 2015) that the frequency of digital technology use affects citizens' creation of political content on web 2.0. However, on the other hand, the data obtained indicates that the level of financial income has a weak impact on citizens' production of political information. These results represent a significant and novel contribution to the bibliography on the digital divide, especially on the factors that determine it, as it contradicts earlier academic research findings (Hargittai; Walejko, 2008; Van-Deursen; Van-Dijk, 2011).

The digital divide is not a matter of financial capital but instead of cultural capital and, in particular, educational capital. The generation of these asymmetries implies a democratic deficit: the access to digital citizenship and to its use are conditioned by factors of the digital gap, primarily by education, that leaves those with a lower level of education in a vulnerable state.

\section{Funding}

This work constitutes part of the research project number CSO2014-52283-C2-1-P, funded by the Ministry of Economy and Competitiveness (Mineco) of the Government of Spain.

It also constitutes part of the research project entitled Medios sociales y activismo político en Internet: hacia una redefinición de los vínculos entre la comunicación y la democracia en la era digital beneficiary of the BBVA Founda- tion Grants to researchers, innovators, and cultural creators awarded in 2014. The BBVA Foundation does not take responsibility for the opinions, comments, and content included in this chapter or any of the results arising therefrom, for which the author is solely and entirely accountable.

\section{Bibliography}

Benkler, Yochai (2015). La riqueza de las redes: cómo la producción social transforma los mercados y la libertad. Barcelona: Icaria. ISBN: 9788498886344

Blank, Grant (2013). "Who creates content? Stratification and content creation on the internet". Information, communication \& society, v. 16, n. 4, pp. 590-612.

https://www.researchgate.net/publication/258245939_ Social_stratification_content_production_A_response https://doi.org/10.1080/1369118X.2013.777758

Bonfadelli, Heinz (2002). "The internet and knowledge gaps. A theoretical and empirical investigation". European journal of communication, v. 17, n. 1, pp. 65-84.

https://www.researchgate.net/publication/249720563 The_Internet_and_Knowledge_Gaps https://doi.org/10.1177/0267323102017001607

Cáceres-Zapatero, María-Dolores; Brändle, Gaspar; RuizSan-Román, José-Antonio (2015). "Hacia la construcción de una ciudadanía digital. Nuevos modelos de participación y empoderamiento a través de internet". Prisma social: revista de ciencias sociales, n. 15, pp. 643-684.

http://hdl.handle.net/10201/47443

Casero-Ripollés, Andreu (2015). “Estrategias y prácticas comunicativas del activismo político en las redes sociales en España". Historia y comunicación social, v. 20, n. 2, pp. 245-260. https://doi.org/10.5209/rev_HICS.2015.v20.n2.51399

Castells, Manuel (2009). Comunicación y poder. Barcelona: Editorial UOC. ISBN 9788420684994

Correa, Teresa (2010). "The participation divide among 'online experts': Experience, skills and psychological factors as predictors of college students' web content creation". Journal of computer-mediated communication, v. 16, n. 1, pp. 71-92.

https://goo.gl/WpQJJn

https://doi.org/10.1111/j.1083-6101.2010.01532.x

Dahlgren, Peter (2013). The political web: Media, participation and alternative democracy. Basingstoke: Palgrave Macmillan. ISBN: 9781137326386

DiMaggio, Paul; Hargittai, Eszter (2001). "From the 'digital divide' to 'digital inequality': Studying Internet use as penetration increases". Working paper series, n. 15. Princeton: Center for Arts and Cultural Policy Studies, Woodrow Wilson School, Princeton University.

https://www.princeton.edu/ artspol/workpap/WP15\%20 -\%20DiMaggio+Hargittai.pdf

Feenstra, Ramón A.; Casero-Ripollés, Andreu (2014). “Democracy in the digital communication environment: A typology proposal of political monitoring processes". International journal of communication, v. 8, pp. 2448-2468.

http://ijoc.org/index.php/ijoc/article/view/2815 
Fuchs, Christian (2014). Social Media: a critical introduction. London: Sage. ISBN: 9781446257319

Fundación Telefónica (2016). La sociedad de la información en España 2015. Madrid: Fundación Telefónica-Ariel. https://goo.gl/XzDQeg

Gladwell, Malcolm (2010). "Small change. Why revolution will not be tweeted". The New Yorker, 4 October. http://www.newyorker.com/magazine/2010/10/04/smallchange-malcolm-gladwell

Hargittai, Eszter; Hsieh, Yuli-Patrick (2013). "Digital inequality". In: Dutton, William H. (ed.). The Oxford handbook of internet studies. Oxford: Oxford University Press, pp. 129-150. ISBN: 9780199589074

Hargittai, Eszter; Walejko, Gina (2008). "The participation divide: content creation and sharing in the digital age". Information, community and society, v. 11 n. 2, pp. 239-256. https://soc334technologyandsociety.files.wordpress. com/2012/08/hargittaiwalejko2008.pdf https://doi.org/10.1080/13691180801946150

Haywood, Trevor (1995). Info-rich/info poor: access and exchange in the global information society. London: Bowker Saur. ISBN: 9780862916312

Hoffmann, Christian-Pieter; Lutz, Christoph; Meckel, Miriam (2015). "Content creation on the internet: A social cognitive perspective on the participation divide". Information, communication \& society, v. 18, n. 6, pp. 696-716. https://doi.org/10.1080/1369118X.2014.991343

Jenkins, Henry (2006). Convergence culture: Where old and new media collide. New York: NYU Press. ISBN: 0814742815

Keane, John (2009). The life and death of democracy. London: Simon and Schuster. ISBN: 9781416526063

Lievrouw, Leah (2011). Alternative and activist new media. Cambridge: Polity. ISBN: 9780745641843

Micó-Sanz, Josep-Lluís; Casero-Ripollés, Andreu (2014). "Political activism online: organization and media relations in the case of 15M in Spain". Information communication \& society, v. 17, n. 7, pp. 858-871.

https://doi.org/10.1080/1369118X.2013.830634

Morozov, Evgeny (2011). The net delusion: the dark side of internet freedom. New York: Public Affairs. ISBN: 978 1610391061
Morozov, Evgeny (2013). To save everything, click here: Technology, solutionism, and the urge to fix problems that don't exist. New York: Public Affairs. ISBN: 978 1846145483

Norris, Pippa (2015). “Movilización política y redes sociales: El ejemplo de la Primavera Árabe". Infoamérica: Iberoamerican communication review, v. 9, pp. 17-36.

https://dialnet.unirioja.es/servlet/articulo?codigo $=5148403$

Schradie, Jen (2011). "The digital production gap: The digital divide and web 2.0 collide". Poetics, v. 39, n. 2, pp. 145-168 https://goo.gl/8P2LW3

https://doi.org/10.1016/j.poetic.2011.02.003

Schradie, Jen (2013). "The digital production gap in Great Britain". Information, communication \& society, v. 16, n. 6, pp. 989-998.

https://goo.gl/8P2LW3

https://doi.org/10.1080/1369118X.2013.799305

Shirky, Clay (2011). "The political power of social media". Foreign affairs, v. 90, n. 1, pp. 28-41.

http://www.cc.gatech.edu/ beki/cs4001/Shirky.pdf

Sung-Tae, Kim; Young-Hwan, Lee (2007). “New functions of Internet mediated agenda-setting: Agenda-rippling and reversed agenda-setting". Korea journalism review, v. 1, n. 2, pp. 3-29.

Tewksbury, David; Rittenberg, Jason (2012). News on the internet. Information and citizenship in the $21^{\text {st }}$ century. Oxford: Oxford University Press. ISBN: 9780195391978

Van-Deursen, Alexander; Van-Dijk, Jan (2011). "Internet skills and the digital divide". New media \& society, v. 13, n. 6, pp. 893-911.

https://doi.org/10.1177/1461444810386774

Van-Dijck, Jose (2013). The culture of connectivity: A critical history of social media. Oxford: Oxford University Press. ISBN: 9780199970780

Wolton, Dominique (1989). "La communication politique: construction d'un modèle". Hermés, v. 4, pp. 27-42.

http://hdl.handle.net/2042/15353

https://doi.org/10.4267/2042/15353

Zallo-Elgueazabal, Ramón (2013). “Comunicación y democracia en el entorno digital”. adComunica, n. 5, pp. 141-174. https://doi.org/10.6035/2174-0992.2013.5.10
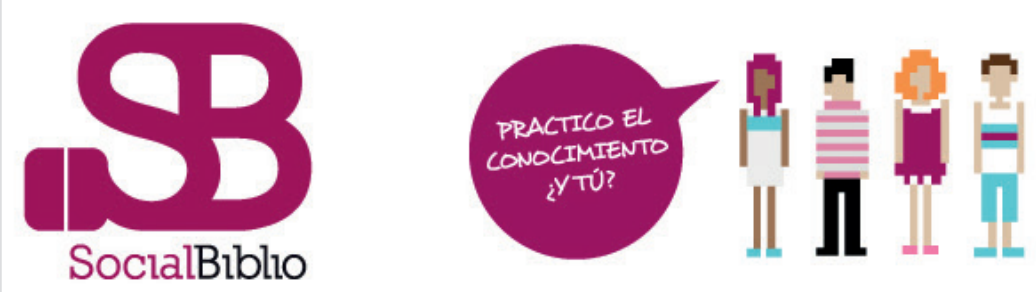

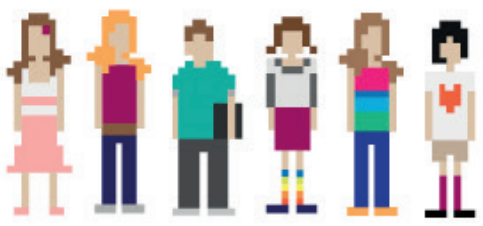

http://www.socialbiblio.com 